\title{
Investigating The Temporal Variation in the Frequency of Smog Precursors in the Ambient Air of Lahore
}

Rabia - Shehzadi ( $\square$ rabia.shehzadi@lcwu.edu.pk)

Lahore College for Women University https://orcid.org/0000-0001-5326-266X

Tahira Aziz Mughal

Lahore College for Women University

Moneeza Abbas

Lahore College for Women University

Amina Abrar

Lahore College for Women University

Ali Abbas

Environmental Protection Department of Punjab

Research Letter

Keywords: Ambient air, PEQS, Photochemical, Pollutant, Smog precursors

Posted Date: March 25th, 2021

DOI: https://doi.org/10.21203/rs.3.rs-331509/v1

License: (c) (i) This work is licensed under a Creative Commons Attribution 4.0 International License. Read Full License 


\section{Abstract}

In present study the seasonal prevalence of smog precursors was analysed to investigate the temporal trend of smog formation in the ambient air of Lahore. Data set of three years (November 2017- April 2020) was obtained from compact ambient air quality monitoring station, installed by Environmental Protection Department on Jail Road, Lahore. Statistical analysis of dataset of smog precursors revealed that in winter, the concentration range of $\mathrm{PM} 10, \mathrm{PM} 2.5, \mathrm{NO}, \mathrm{NO}_{2}$ was significantly higher than Punjab Environmental Quality Standards and WHO Air Quality Guidelines. Whereas in summer, tropospheric ozone recurrence was higher and showed significantly negative correlation with $\mathrm{NO}>\mathrm{PM} 2.5>\mathrm{NO}_{2}>\mathrm{SO}_{2}$ and null association with PM10. Seasonal impact on smog precursors concentration was further approved by correlation analysis of weather component with air pollutants. According to statistical analysis, Ozone $\left(\mathrm{O}_{3}\right)$ was found to have high positive correlation with temperature > wind speed >relative humidity >sunshine hour while inverse relation with air pressure while $\mathrm{NO}, \mathrm{NO}_{2}, \mathrm{SO}_{2}, \mathrm{PM} 2.5$ showed positive corelation with air pressure and negative correlation with temperature, sunshine, and wind speed. These factual figures revealed that ambient air of Lahore has been experiencing reducive-type smog in winter which is acidic in nature and oxidative-type photochemical smog in summer since 2017.

\section{Introduction}

Deteriorating air quality have become a major concern globally due to detrimental socioeconomic and environmental impacts. Pathogenicity of air pollutant depends upon their size, concentration, and origin. Although the biogenic and anthropogenic both sources contribute in the immense release of pollutants in ambient air (Gurjar et al., 2008). But the empirical data on air revealed that industrial revolution has introduced the world to various types of toxic pollutants since $18^{\text {th }}$ century (IPCC, 2014). The excessive use of low-quality fossil fuel in combustion processes, is found responsible for the emission of greenhouse gases beyond threshold level. Fossil fuel has become a major demand not only for domestic stove at micro level to power plant at macroscale for the provision of energy and this has given rise to concentration of greenhouse gases . According to Abas et al. (2017) energy sector (25\%), agriculture (24\%), industry (21\%) transport (14\%), energy related activities (10\%) and buildings (6\%), all contribute in the emission of GHG at global level. Increasing level of greenhouse gases in ambient air have been leading to the escalation of adverse environmental consequences in form of global warming, climate change and ozone depletion. World temperature has risen to $0.74{ }^{\circ} \mathrm{C}$ since 1961 and temperature will further rise to $1.5^{\circ} \mathrm{C}$ to $1.8^{\circ} \mathrm{C}$ during $21^{\text {st }}$ century (Ramanathan \& Feng , 2009). These climatic changes have worsened the fate of air pollutant in photochemical transformation reactions and created extra-terrestrial hazard in form of Smog. The gaseous by-products combine with fog near ground surface under temperature inversion condition and produce tiny drops of acid aerosols to form Smog (Houghton et al., 2001). Mostly PM2.5 is recognized as major agent for the formation of smog worldwide. Carbon, Nitrogen, and Sulphur , constitute the 70-80 \% mass of PM2.5 , are responsible for their pollutant carrying capacity (Poschl,2005; Saltzman et al.,1983). First incident of smog was experienced in London in 1952 that led to death of several thousand people from respiratory disorders. The London smog is also known as sulphurous smog as it originated due to the excessive use of sulphur-based coal (Bell et al., 2001). Afterward Los-Angeles smog that was the product of photochemical 
smog and killed hundreds of people. Afterward, Beijing, Shangai, China, Cairo, Egypt, Brlgrade, Yogosalavia, Calcutta and India faced the worst impact of smog on population (Mohammadi et al., 2012 ; Chen et al., 2013; Shabbir et al ., 2019). Hence Pakistan has also been facing the episodes of smog from last five years. Mostly the air pollution index of Pakistan remained at 77 but pollution index of Pakistan reached to 300 points and became 4th polluted country. Not only the internal sources of emission but the transboundary air pollution is also contributing to degrade the air quality of the country. Because moonsoons sweep all the haze and smog from india and china into Pakistan and north western states. Natural wind flow pattern shifts pollutant into downwind countries . in south asia, natural winds enters from south west ,flow over india turning west to enter into Pakistan (NAP,2015). Furthermore, natural process of air purification has become insufficient and created heat island effect in cities. Because Pakistan produce $60 \%$ electricity using gas and furnace oil. Out of which coal contribute (37\%), petroleum (39\%), natural gas (24\%).This fuel combustion release 158.10 MT of CO2 (54\%), 111.60 MT of CH4 (36\%), 27.90 MT of N2O $(9 \%), 2.17 \mathrm{MT}$ of $\mathrm{CO}(0.75)$ and $0.93 \mathrm{MT}$ of Volatile organic compound in air (Ramay et al., 2011) when These emissions trap in the parcel of static cold air due to meteorological conditions and result in the formation of smog (Gaffney et al., 2009) . This human induced meteorological hazard has been occurring in Pakistan from last five years (Butt, 2017). Especially in Punjab, thick cover of smog has caused the massive increase in the cases of allergies, itchy skins, sore throat, chest burns, respiratory hitches, eyes and nose irritations. Murky cloud of smog killed dozens in road accidents, hospitalized 1200 elders and 700 children during the year 2016 (Raza et al., 2020).

Research objective: Main objective of this study is to decipher time series data of smog precursors e.g. nitrogen oxide, nitrogen dioxide, sulphur dioxide, particulate matter, ozone and weather components e.g., ambient temperature, air pressure, wind speed, relative humidity and sun shine hours to characterize the frequently occurring smog event in the ambient air of Lahore.

\section{Methodology}

Temporal variation in the content of smog precursors and the impact of meteorological factors on their prevalence was studied in the ambient air of Lahore (Czerwińska, 2020). Lahore is the country's secondmost populous city, lying between $31^{\circ} 15^{\prime}-31^{\circ} 45^{\prime} \mathrm{N}$ and $74^{\circ} 01^{\prime}-74^{\circ} 39^{\prime} \mathrm{E}$. Its climate is five season semi-arid climate according to Koppen Classification (Butt,2017). The Lahore city experience combination of weather with hottest June $\left(<40^{\circ} \mathrm{C}\right)$, wettest July with heavy rainfall and coolest January with dense fog. Lahore has been facing the episodes of smog every winter since 2015 due to uncontrolled elevated level of air pollution (Haider et al., 2017)

To examine the prevalence of smog precursors in the ambient air, Jail Road (Fig.1) was selected. This 5km long road depicts the features of commercial zone and is located in the centre of Lahore. To characterize the emission sources, several visits to Jail Road were made for visual observations. Data set from November 2017 to April 2020 was obtained from compact ambient air quality monitoring station (CAAQMS: Air pointer MLU Recordum Austria Europe) installed by Environmental Protection Department in the premises of Meteorological Department on Jail Road. This CAAQMS was equipped with sensors and module in which UV-Absorption method, chemiluminescence and NDIR were used to measure Particulate Matter 
(PM2.5 $\mu \mathrm{g} / \mathrm{m}^{3}$ and PM10 $\left.2.5 \mu \mathrm{g} / \mathrm{m}^{3}\right)$, Nitrogen dioxide $\left(\mathrm{NO}_{2} \mu \mathrm{g} / \mathrm{m}^{3}\right)$, Nitric oxide $\left(\mathrm{NO} \mu \mathrm{g} / \mathrm{m}^{3}\right)$, Sulphur dioxide $\left(\mathrm{SO}_{2}\right)$ and Ozone $\left(\mathrm{O}_{3} \mathrm{\mu g} / \mathrm{m}^{3}\right)$. Furthermore, preliminary data on metrological parameters such as sunshine hours, temperature $\left({ }^{\circ} \mathrm{C}\right)$, wind speed $(\mathrm{knot})$, air pressure $(\mathrm{mb})$ and relative humidity $(\%)$ was also examined for the present study. Data regarding ambient air pollutants and metrological components was subjected to statistical analysis to assess the impact of weather component on smog precursors and smog formation trend.

\section{Results}

Temporal variation in the content of smog precursors and the impact of meteorological factors on their prevalence and smog formation was studied in the ambient air of Lahore. For compliance, permissible limits of ambient air quality from Punjab environmental quality Standards (PEQS,2016) and WHO Air Quality Guidelines,2005 were used (Table.1)

\subsection{Temporal Variation of Smog Precursors in Ambient Air}

Trend analysis of temporal concentration range of PM10(Fig.2), PM 2.5(Fig.3), NO(Fig.4), $\mathrm{NO}_{2}(\mathrm{Fig} .5), \mathrm{SO}_{2}$ (Fig.6) showed a significant cyclic rise in cold season and fall in hot season in the ambient air of Jail Road, Lahore. Whereas tropospheric ground level ozone showed a significant periodic rise in summer and fall in cold season in the ambient air. Compliance of results showed that concentration range of PM10, PM 2.5, $\mathrm{NO}, \mathrm{NO}_{2}$ from November to February had been significantly above and the temporal concentration range of $\mathrm{SO}_{2}$ and $\mathrm{O}_{3}$ was found below the limits prescribed by PEQS. However temporal concentration range of PM $10, \mathrm{PM} 2.5, \mathrm{NO}, \mathrm{NO}_{2}$ and $\mathrm{SO}_{2}$ was found significantly above and temporal concentration range of tropospheric ozone was found below the $\mathrm{WHO}$ air quality guideline.

\subsection{Co-Existence Analysis of Smog Precursors}

To determine the coexistence of smog precursors ,Dot plot analysis was used and result showed the (fig.8) temporal concentration extent of PM10 $\left(21.98 \mu \mathrm{g} / \mathrm{m}^{3}-307.76 \mu \mathrm{g} / \mathrm{m}^{3}\right), \mathrm{PM} 2.5\left(10.49 \mu \mathrm{g} / \mathrm{m}^{3}-176 \mu \mathrm{g} / \mathrm{m}^{3}\right)$, $\mathrm{NO}\left(04 \mu \mathrm{g} / \mathrm{m}^{3}-250 \mu \mathrm{g} / \mathrm{m}^{3}\right), \mathrm{NO}_{2}\left(9.85 \mu \mathrm{g} / \mathrm{m}^{3}-127 \mu \mathrm{g} / \mathrm{m}^{3}\right), \mathrm{SO}_{2}\left(9.4 \mu \mathrm{g} / \mathrm{m}^{3}-99.17 \mu \mathrm{g} / \mathrm{m}^{3}\right)$ and $\mathrm{O}_{3}\left(20.7 \mu \mathrm{g} / \mathrm{m}^{3}\right.$ $\left.-107 \mu \mathrm{g} / \mathrm{m}^{3}\right)$ in the ambient air of Jail road and further subjected to Pearson correlation analysis.According to Pearson correlation analysis, $\mathrm{PM} 10$ has positive correlation with $\mathrm{PM} 2.5(\mathrm{r}=0.7)>\mathrm{NO}_{2}(\mathrm{r}=0.46)>\mathrm{NO}(\mathrm{r}=$ $0.32), \mathrm{SO}_{2}(r=0.1)$, ozone $(r=.03)$ whereas $\mathrm{PM} 2.5$ has a significant positive correlation with $\mathrm{NO}(\mathrm{r}=0.80)$ $>\mathrm{NO}_{2}(\mathrm{r}=0.78)>\mathrm{PM} 10(\mathrm{r}=0.72)>\mathrm{SO}_{2}(\mathrm{r}=0.25)$ and negative correlation with ozone $(\mathrm{r}=-0.45)$ while $\mathrm{NO}_{2}$ has strong positive correlation with $\mathrm{NO}(\mathrm{r}=0.85)>\mathrm{PM} 2.5(\mathrm{r}=0.78)>\mathrm{PM} 10(\mathrm{r}=0.46)>\mathrm{SO}_{2}(\mathrm{r}=0.35)$. Furthermore, NO has strong positive correlation with $\mathrm{PM} 2.5(\mathrm{r}=0.81)>\mathrm{PM} 10(\mathrm{r}=0.32)$. Although $\mathrm{SO}_{2}$ has high positive correlation with $\mathrm{NO}(r=0.80)>\mathrm{NO} 2(r=0.35)>\mathrm{PM} 2.5(r=0.256)>\mathrm{PM} 10(r=0.1)$. While ozone has null association with PM10(r=0.032) but highly negative association with $\mathrm{NO}(r=-0.5), \mathrm{PM} 2.5(r=-0.457)>\mathrm{NO} 2(r=-0.26)$ $>\mathrm{SO} 2(\mathrm{r}=-0.247)$.

\subsection{Impact Assessment of meteorological Factors on smog precursors}


Effect of metrological parameters (Table.2) such as sunshine hours, temperature $\left({ }^{\circ} \mathrm{C}\right)$, wind speed $(\mathrm{knot})$, air pressure $(\mathrm{mb})$ and relative humidity $(\%)$ were studied on smog precursors and result (Fig.9) showed that windspeed have positive association with Ozone $(r=0.8099)>S O 2(r=0.7284)>P M 10(r=0.7127)>P M 2.5(r=$ $0.0183)$.Null association was found with $\mathrm{NO}(\mathrm{r}=0.051)$ whereas highly negative correlation was found with $\mathrm{NO2}(r=-0.714)$. Air pressure have positive association with PM2.5 $(r=0.8422)>P M 10(r=0.8067)>\mathrm{NO}_{2}(r=0.7)$ $>\mathrm{NO}(\mathrm{r}=0.603)>\mathrm{SO}_{2}(\mathrm{r}=-0.3565)$ whereas highly negative correlation was found with $\mathrm{O}_{3}(\mathrm{r}=-0.9834)$. Cloud Percentage have positive association with $\mathrm{O}_{3}(r=0.5788)>\mathrm{NO}(r=0.4)>\mathrm{SO}_{2}(r=0.1553)$ whereas highly negative correlation was found with PM2.5( $r=-0.7333)>P M 10(r=-0.6599)>\mathrm{NO}_{2}(r=-0.0542)$. Relative Humidity have positive association with $\mathrm{O}_{3}(r=0.8074)>S O 2(r=0.8008)>P M 10(r=0.2479)$ whereas highly negative correlation was found with $\mathrm{NO}(\mathrm{r}=-0.3942)>\mathrm{NO}_{2}(\mathrm{r}=-0.385)>\mathrm{PM} 2.5(\mathrm{r}=-0.284)$. Temperature have positive association with $\mathrm{O}_{3}(\mathrm{r}=0.8873)$ whereas highly negative correlation was found with $\mathrm{PM} 10(\mathrm{r}=$ $-0.6032)>\mathrm{NO}_{2}(\mathrm{r}=-0.584)>\mathrm{PM} 2.5(\mathrm{r}=-0.476)>\mathrm{NO}(\mathrm{r}=-0.3601)>\mathrm{SO}_{2}(\mathrm{r}=-0.1303)$. Sunshine hours have positive association with the Ozone $(r=0.7)>\mathrm{SO}_{2}(r=0.4)$ in the ambient air of Jail road whereas PM2.5( $\left.r=-0.769\right)$ $>P M 10(r=-0.76)>\mathrm{NO}(r=-0.67)>\mathrm{NO}_{2}(r=-0.32)$ have negative correlation with sunshine hours.

\section{Discussion}

Study on the variation in the prevalence of smog precursors species in the ambient air of Lahore was carried out to assess the temporal extent of gaseous by-product in air and impact of meteorological factors on their recurring trend. Major pollutants selected for current study were oxides of nitrogen, sulphur, ozone, and particulate matter as they are identified as instigator for smog with substantial evidence. Sources of the release of these air pollutants are dust generating activities, burning of biogenic material and combustion of low-quality fossil fuel which are well apportioned on roads with heavy traffic load, Industries, and agricultural sites near and around Lahore.In present study, the Data set of three years for scrutiny was obtained from the air quality monitoring station that was installed in meteorological department on Jail Road . Jail Road, Lahore is a $5 \mathrm{~km}$ long 3 lane road that scored the features of commercial zone e.g., hospitals, educational institutes, police station, departmental stores, restaurants, recreational parks, car showrooms, Fuel pumps stations and housing societies on roadside. This road is located almost on the centre of Lahore city. The intense agglomeration of high grade public and private services cause the high influx of vehicles ( $>0.1$ million) in this area, often create traffic congestion in daytime. Therefore,in current study, temporal monthly mean extent of PM-10 $\left(21.98 \mu \mathrm{g} / \mathrm{m}^{3}-307.76 \mu \mathrm{g} / \mathrm{m}^{3}\right), \mathrm{PM} 2.5\left(10.49 \mu \mathrm{g} / \mathrm{m}^{3}-176\right.$ $\left.\mu \mathrm{g} / \mathrm{m}^{3}\right)$, NO $\left(04 \mu \mathrm{g} / \mathrm{m}^{3}-250 \mu \mathrm{g} / \mathrm{m}^{3}\right), \mathrm{NO}_{2}\left(127 \mu \mathrm{g} / \mathrm{m}^{3}-9.85 \mu \mathrm{g} / \mathrm{m}^{3}\right)$ was found to be higher than the permissible limits of PEQS. Whereas $\mathrm{SO}_{2}\left(99.17 \mu \mathrm{g} / \mathrm{m}^{3}-9.4 \mu \mathrm{g} / \mathrm{m}^{3}\right)$ and ozone $\left(107 \mu \mathrm{g} / \mathrm{m}^{3}-20.7 \mu \mathrm{g} / \mathrm{m}^{3}\right)$ was found below standards in the ambient air of Jail road .

First Reason is attributed to type of fuel used in vehicles. Large proportion ( $>70 \%)$ of vehicles use petrol followed by Compressed natural gas (CNG) on second, Liquified petroleum gas (LPG) on third and diesel on fourth . while scientific evidences proves that $\mathrm{CNG}$ is more cleaner in term of $\mathrm{CO}_{2}, \mathrm{CO}$ and $\mathrm{SO}_{2}, \mathrm{LPG}$ is cleaner in term of $\mathrm{NO}_{2}, \mathrm{NO}$ and petrol is cleaner in term of hydrocarbon (Hameed,2013). Along with the quality and type of fuel, increase in number of point sources further aggravate the emission factor as the 
rise in city traffic has reached to 6.2 million vehicles at $10 \%$ annual increase rate since 2005 . Out of which, 4.2 million motorcycles , 2.4 million non-commercial cars, 0.24 million rikshaw, 0.004 million motorcycle rikshaw are on road while the rest are delivery vans ,buses and trucks (Butt,2018; Shah et al ., 2020). Therefore, $70 \%$ air pollution in city is attributed to Traffic pollution .Out of which $40 \%$ is from poorly maintained auto rikshaws, pickups and diesel buses. Hence further decline in recurring content of air pollutants could be attributed to the initiative taken by Government in 2016 after worst episode of smog in city (Hameed et al., 2013). Which include the import and supply of low sulphur fuel to local markets . Fuel sector imported first environmental friendly low sulphur diesel of 500 ppm in 2017, LNG in 2015 and higher $92 / 95$ grade gasoline in November 2016. Sulphur dioxide is formed by the oxidation of sulphur compound in petroleum /coal as fuel which further lead to acid rain (Afon \& Ervin , 2008). This minor change in fuel quality has led to visible decrease in sulphur emission. Further governmental actions include the strict implementation of smog policy reforms at provincial level since 2016 which involved shutting down dust generating activities , banning of stubble burning , municipal solid waste burning , closure of brick kiln in winter season for three months fine/challan on pollution generating vehicles and industries every year all over the province. Other structural measures include the widening and construction of signal free roads in Lahore Which contributed in the minimization of fuel combustion emission (PDMA,2016).

Second reason for fluctuation in temporal prevalence of air pollutant is the intermediate gaseous reactions in ambient air because a significant positive correlation of PM10 and PM2.5 with $\mathrm{NO}(r=0.80)>\mathrm{NO}_{2}(r$ $=0.78)>\mathrm{SO}_{2}(r=0.25)$ and negative correlation with ozone $(r=-0.45)$ was analysed from dataset. Particles smaller than $2.5 \mu \mathrm{m}$ are considered fine particles which originate from secondarily formed aerosols, (gas-toparticle conversion) combustion particles, recondensed organic and metal vapours. According to Park et al. (2007) sulphur dioxide oxidise in the atmosphere to form sulphuric acid $\left(\mathrm{H}_{2} \mathrm{SO}_{4}\right)$. which can be neutralized by $\mathrm{NH}_{3}$ to form ammonium sulphate. Sulphate aerosols mostly makes the $6 \%-28 \%$ of particulate matter of 2.5 micron Nitrogen dioxide is oxidised to nitric acid $\left(\mathrm{HNO}_{3}\right)$ which in turn can react with ammonia to form ammonium nitrate $\left(\mathrm{NH}_{4} \mathrm{NO}_{3}\right)$. These secondary particles are the dominant part of fine particles produced from the intermediate reaction of gases. Particulate matter is composed of $28.7 \%$ organic matter , $21.4 \%$ sulphate, $15 \%$ nitrate, $12.8 \%$ ammonium, $8.8 \%$ elemental carbon and remaining percentage of trace metals . Another study by Viidanoja et al. (2002) revealed that oxidation of VOC gives rise to carbonaceous fractions and black carbon in air. Ozone highly negative association with $\mathrm{NO}(r=-0.5), \mathrm{PM} 2.5(\mathrm{r}=-0.457)>\mathrm{NO}_{2}(\mathrm{r}=$ $-0.26)>\mathrm{SO}_{2}(r=-0.247)$ because oxidation of carbon mono-oxide, nitrogen dioxide, hydroxide and VOCs triggered by photochemical reactions result in elevated ground level tropospheric ozone in summer (Uzoigwe et al., 2013). Whereas lifetime of Sulphur dioxide in atmosphere is 1-3 days due to the ubiquitous photochemical sink because hydroxyl radical oxidize the sulphur dioxide to sulphate aerosols in gas phase in day time (Rotstayn and Lohamann,2002).

Third reason for variation of concentration of PM10, $\mathrm{PM} 2.5, \mathrm{SO}_{2}, \mathrm{NO}_{2}, \mathrm{O}_{3}$ at intermonth temporal scale is response of smog precursors to sunshine hours, temperature, Air pressure, Wind speed, relative humidity and cloud percentage. Air flow have positive association with Ozone $>\mathrm{SO}_{2}>\mathrm{PM} 10>\mathrm{PM} 2.5$. The reason is attributed to the factor that trigger the speed of air flow e.g., In summer, wind convection due to high temperature cause vertically upward movement of pollutant and disperse them in air. The dilution effect of 
wind speed on pollutant rises at first and then tends to be gentle. Because the particles can be carried out over long distance by wind and then settle on the ground, vegetation or water where they further begin/trigger the disruptions of ecological processes and damages to aesthetic damages (Kgabi and Mokgwetsi , 2009) high wind speed (>12 m/s) cause more dispersion and dilution. Air pressure have positive association with $\mathrm{PM} 2.5>\mathrm{PM} 10>\mathrm{NO}_{2}>\mathrm{NO}>\mathrm{SO}_{2}$ whereas highly negative correlation with $\mathrm{O}_{3}$ because Under the low-pressure circulation situation, there are more rainy days and the wind direction changes more frequently, which helps the diffusion and dilution of particulate matter; while the highpressure circulation situation brings more sunny days and the weather system is relatively stable, forcing the particulate matter to be stagnate in the near-surface layer. In this way, an inversion can prevent the rise and dispersal of pollutant from lower layer cause a localized air pollution problem Hence, the response of Pollutants to air pressure appears to be positive on a large time scale. Relative humidity and Cloud Percentage have positive association with $\mathrm{O}_{3}>\mathrm{SO}_{2}$ whereas highly negative correlation with PM2.5> PM10 $>\mathrm{NO}_{2}>\mathrm{NO}$ because high humidity environment has the effect of agglomerating PM 2.5. High sulphur produce high concentration of sulfuric acid when combine with fog droplets. formation of these acidic particles aggravated by dampness and high concentration of particulate matter in air (Rani et al., 2011). because $\mathrm{SO}_{2}$ react with cloud or fog produce more sulphate aerosol. According to Griffing (1977) NOx concentrations are more elevated during the wet season. Because the frequently recurring thunder storm flashes produce oxide of nitrogen. Temperature and sunshine hours have positive association with 03 and highly negative correlation with PM10 $>\mathrm{NO}_{2}>\mathrm{PM} 2.5>\mathrm{NO}>\mathrm{SO}_{2}$. According to Tecer et al. (2008) higher heat deficit is associated with less turbulence thus cause high concentration of Particulate matter while low heat deficit associated with high turbulence that cause low particulate matter in summer. Hence high temperature ( $>24 \mathrm{C}$ ) cause more dilution than dispersion which is observed more in summer than winter where under strong temperature inversion condition, wet ground due to precipitation trap more pollutant near to their sources. Whereas Plocoste et al. (2018) reported that temperature, high UV index and sunshine hours strongly influence the amplitude of ozone cycles. Because these factors trigger the high occurrence rate of photochemical reaction in which brownish oxidative smog formed (Derwent et al., 2016).

\section{Conclusion}

Current studies revealed that the winter maximum mean values of PM10 $\left(307.76 \pm 54.9 \mu \mathrm{g} / \mathrm{m}^{3}\right)$, $\mathrm{PM} 2.5\left(176 \pm 89 \mu \mathrm{g} / \mathrm{m}^{3}\right), \mathrm{NO}\left(250 \pm 35 \mu \mathrm{g} / \mathrm{m}^{3}\right), \mathrm{NO}_{2}\left(127 \pm 07 \mu \mathrm{g} / \mathrm{m}^{3}\right)$ was found significantly higher than Punjab Environmental Quality Standards (PEQS,2016) Whereas $\left(\mathrm{O}_{3}\right)$ tropospheric ozone recurrence was higher in summer while pearson correlation analysis showed negative association of $\mathrm{O}_{3}$ with $\mathrm{NO}>\mathrm{PM} 2.5>\mathrm{NO}_{2}>\mathrm{SO}_{2}$ and null association with PM10. These findings were further approved by correlation analysis of weather component with air pollutant prevalence .According to statistical analysis, Ozone $\left(\mathrm{O}_{3}\right)$ was found to have high positive correlation with temperature $>$ wind speed >relative humidity >sunshine hour while inverse relation with air pressure while $\mathrm{NO}, \mathrm{NO}_{2}, \mathrm{SO}_{2}, \mathrm{PM} 2.5$ showed positive corelation with air pressure and negative correlation with temperature, sunshine and wind speed.These findings were in compliance with the studies done by Czerwińska (2020) and Mohammadi et al.(2012) . These facts are evident that ambient air 
of Lahore is experiencing reducive-type smog in winter which is acidic in nature and oxidative-type photochemical smog in summer.

\section{Declarations}

\section{*Authors' Contributions}

Rabia Shehzadi: Methodology, Data collection, Result interpretation

Tahira Aziz Mughal \& Moneeza Abbas: Original Draft preparation

Amina Abrar: Review and editing,

Ali abbas: Resources

All authors read and approved the final manuscript.

\section{*Acknowledgements}

We acknowledge the support of Environmental Protection Department, Punjab And Meteorological Department Lahore, Pakistan

*Conflicts of interests/Competing interests.

We have no interest of conflict to disclose and declare no competing interest.

\section{*Availability of data and material}

Data is original and would be shared on request.

*Ethics approval and consent to participate.

Not Applicable

*Funding

Not applicable

\section{*Additional information}

None

*Consent Publication

All authors have agreed to the submit the article in this journal.

\section{References}


1. Abas N, Kalair A, Khan N, Kalair AR (2017) Review of GHG emissions in Pakistan compared to SAARC countries. Renew Sustain Energy Rev. 80: 990-1016.

2. Shah SIH, Nawaz R, Ahmad S ,Arshad M (2020) Sustainability Assessment of Modern Urban Transport and Its Role in Emission Reduction of Greenhouse Gases: A Case Study of Lahore Metro Bus. Kuwait J Sci. 47(2).

3. Bell ML, Davis DL (2001) Reassessment of the lethal London fog of 1952: novel indicators of acute and chronic consequences of acute exposure to air pollution. Environ Health Perspect, 109 (suppl 3): 389394.

4. Butt MT, Abbas N, Deeba F, Iqbal J, Hussain N, Khan RA (2018) Study of Exhaust Emissions from Different Fuels based Vehicles in Lahore City of Pakistan. Asian J Chem.30(11): 2481-2485.

5. Butt WH (2017) Distributing destruction: Construction, waste and atmospheres in Lahore. City. 21(5): 614-621.

6. Chen R, Zhao Z, Kan H (2013) Heavy smog and hospital visits in Beijing, China. Am J Respir Crit Care Med. 188(9): 1170-1171.

7. Czernecki et al (2017) Influence of the atmospheric conditions on PM 10 concentrations in Poznań, Poland. J Atmos Chem. 74(1): 115-139.

8. Czerwińska J, Wielgosiński G (2020) The effect of selected meteorological factors on the process of" Polish smog" formation. J Ecol Eng. 21(1).

9. Derwent et al (2016). Interhemispheric differences in seasonal cycles of tropospheric ozone in the marine boundary layer: Observation-model comparisons. J Geophys Res Atmos.121(18): 11-75

10. Gaffney SJ, Marley NA, Frederick JE (2011) Formation and effects of smog. Environmental and ecological chemistry. In Encyclopedia of Life Support Systems (EOLSS) (Vol. 2).

11. Griffing GW (1977) Ozone and oxides of nitrogen production during thunderstorms. J Geophys Res. 82(6): 943-950

12. Gurjar BR, Butler TM, Lawrence MG, Lelieveld J (2008). Evaluation of emissions and air quality in megacities. Atmos Environ. 42(7): 1593-1606

13. Hameed R, Bhatti NA, Nadeem O, Haydar S, Khan MA (2013) Comparative Analysis of Emissions from Motor Vehicles Using LPG, CNG and Petrol as Fuel in Lahore. JPIChE. 41(1): 59-66

14. Houghton et al (2001) Climate Change 2001: The Scientific Basis, Climate Change 2001: 57.

15. NAP (2015) Review of the draft interagency report on the impacts of climate change on human health in the United States. Washington, D.C.: National Academies Press https://www.nap.edu/catalog/21787/review-of-the-draft-interagency-report-on-the-impacts-of-climatechange-on-human-health-in-the-united-states

16. IPCC (2014). Mitigation of climate change. Contribution of Working Group III to the Fifth Assessment Report of the Intergovernmental Panel on Climate Change (IPCC), 1454

17. Kgabi NA, Mokgwetsi T (2009) Dilution and dispersion of inhalable particulate matter. WIT Trans Ecol Environ. 127: 229-238. 
18. Park SS, Kim YJ, Cho SY, Kim SJ (2007) Characterization of PM2. 5 aerosols dominated by local pollution and Asian dust observed at an urban site in Korea during aerosol characterization experiments (ACE)-Asia Project. J Air \& Waste Manag Assoc. 57(4): 434-443.

19. PDMA, 2017. Precautionary Measures Against SMOG. http://pdma.gop.pk/node/373

20. Plocoste T, Dorville JF, Monjoly S, Jacoby-Koaly S, André M (2018) Assessment of nitrogen oxides and ground-level ozone behavior in a dense air quality station network: Case study in the Lesser Antilles Arc. J Air \& Waste Manag Assoc. 68(12): 1278-1300.

21. Pöschl U (2005) Atmospheric aerosols: composition, transformation, climate and health effects. Angew Chem Int. 44(46): 7520-7540.

22. Mohammadi H, Cohen D, Babazadeh M, Rokni L (2012) The effects of atmospheric processes on Tehran smog forming. Iran J public health, 41(5):1.

23. PEQS Punjab Environmental Quality Standard, (2016) https://epd.punjab.gov.pk/peqs

24. Ramanathan V, Feng Y (2009) Air pollution, greenhouse gases and climate change: Global and regional perspectives. Atmos environ. 43(1): 37-50

25. Rani B, Singh U, Chuhan AK, Sharma D, Maheshwari R (2011). Photochemical Smog Pollution and Its Mitigation Measures. J Adv Sci Res. 2(4).

26. Raza W, Saeed S, Saulat H, Gul H, Sarfraz M, Sonne C, Kim KH (2020) A review on the deteriorating situation of smog and its preventive measures in Pakistan. J Clean Prod. 123676.

27. Rotstayn LD, Lohmann U (2002) Tropical rainfall trends and the indirect aerosol effect. J Clim. 15(15): 2103-2116.

28. Saleem Z, Saeed H, Yousaf M, Asif U, Hashmi F K, Salman M. Hassali MA (2019) Evaluating smog awareness and preventive practices among Pakistani general population: a cross-sectional survey. Int $\mathrm{J}$ Health Promot Educ. 57(3): 161-173.

29. Saltzman ES, Brass GW, Price DA (1983) The mechanism of sulfate aerosol formation: Chemical and sulfur isotopic evidence. Geophys Res Lett. 10(7): 513-516.

30. Shabbir M, Junaid A, Zahid J (2019). Smog: A transboundary issue and its implications in India and Pakistan. https://www.think-asia.org/handle/11540/9584

31. Tecer LH, Süren P, Alagha O, Karaca F, Tuncel G (2008) Effect of meteorological parameters on fine and coarse particulate matter mass concentration in a coal-mining area in Zonguldak, Turkey. J Air \& Waste Manag Assoc. 58(4): 543-552.

32. Uzoigwe JC, Prum T, Bresnahan E, Garelnabi M (2013). The emerging role of outdoor and indoor air pollution in cardiovascular disease. N Am J Med Sci , 5(8): 445.

33. Viidanoja J, Kerminen VM, Hillamo R (2002). Measuring the size distribution of atmospheric organic and black carbon using impactor sampling coupled with thermal carbon analysis: Method development and uncertainties. Aerosol Sci Technol. 36(5):607-616.

34. Von Schneidemesser E, Stone E A, Quraishi TA, Shafer MM, Schauer JJ (2010). Toxic metals in the atmosphere in Lahore, Pakistan. Sci Total Environ. 408(7): 1640-1648. 
35. Afon Y , Ervin D(2008) An Assessment of Air Emissions from Liquefied Natural Gas Ships Using Different Power Systems and Different Fuels, J Air \& Waste Manag Assoc, 58:3, 404411, DOI: 3155/1047-3289.58.3.404

\section{Tables}

Table 1. Ambient Air quality limits prescribed by Punjab Environmental Quality Standards (2016) and WHO Air Quality Guidelines (2005)

\begin{tabular}{|c|c|c|c|}
\hline \multirow{2}{*}{$\begin{array}{l}\text { Sr. } \\
\text { no }\end{array}$} & \multirow[b]{2}{*}{ Parameters } & \multicolumn{2}{|c|}{ Air Quality Standards / Guidelines } \\
\hline & & WHO, 2005 & PEQS,2016 \\
\hline 1. & $\begin{array}{l}\text { Particulate matter } \\
\text { (PM 10) }\end{array}$ & $50 \mu \mathrm{g} / \mathrm{m}^{3} 24$-hour mean & $150 \mu \mathrm{g} / \mathrm{m}^{3}$ 24-hour mean \\
\hline 2. & $\begin{array}{l}\text { Particulate matter } \\
\text { (PM 2.5) }\end{array}$ & $25 \mu \mathrm{g} / \mathrm{m}^{3} 24$-hour mean & $35 \mu \mathrm{g} / \mathrm{m}^{3} 24$-hour mean \\
\hline 3. & Nitrogen Dioxide (NO2) & $\begin{array}{l}40 \mu \mathrm{g} / \mathrm{m}^{3} \text { annual mean } \\
200 \mu \mathrm{g} / \mathrm{m}^{3} 1 \text {-hour mean }\end{array}$ & $80 \mu \mathrm{g} / \mathrm{m}^{3} 24$-hour mean \\
\hline 4. & Nitrogen Oxide (NO) & - & $40 \mu \mathrm{g} / \mathrm{m}^{3} 24$-hour mean \\
\hline 5. & Sulphur Dioxide (SO2) & $20 \mu \mathrm{g} / \mathrm{m}^{3} 24$-hour mean & $120 \mu \mathrm{g} / \mathrm{m}^{3} 24$-hour mean \\
\hline 6. & Ozone (03) & $100 \mu \mathrm{g} / \mathrm{m}^{3}$ 8-hour mean & $130 \mu \mathrm{g} / \mathrm{m}^{3} 1$-hour mean \\
\hline
\end{tabular}

Table 2. Temporal extent of weather component in Lahore 


\begin{tabular}{|c|c|c|c|c|c|c|c|}
\hline \multirow[b]{2}{*}{ Season } & \multirow[b]{2}{*}{ Month } & \multicolumn{6}{|c|}{ Monthly Mean } \\
\hline & & $\begin{array}{l}\text { Sunshine } \\
\text { (Hours) }\end{array}$ & $\begin{array}{l}\text { Relative } \\
\text { Humidity } \\
\%\end{array}$ & $\begin{array}{l}\text { Cloud } \\
\text { Percentage } \\
\text { (\%) }\end{array}$ & $\begin{array}{l}\text { Wind } \\
\text { Speed } \\
\text { (knot) }\end{array}$ & $\begin{array}{l}\text { Ambient Air } \\
\text { Temperature } \\
\left({ }^{\circ} \mathrm{C}\right)\end{array}$ & $\begin{array}{l}\text { Atmospheric } \\
\text { pressure } \\
\text { (mb) }\end{array}$ \\
\hline \multirow[t]{3}{*}{ Spring } & February & 7.38 & 37.9 & 2.95 & 4.56 & 22.15 & 991 \\
\hline & March & 8.3 & 54 & 2.675 & 2.5 & 27.9 & 988.05 \\
\hline & April & 9.2 & 42.5 & 2.325 & 2.35 & 35 & 984 \\
\hline \multirow[t]{2}{*}{ Summer } & May & 9.8 & 34 & 1.9 & 2.25 & 38.45 & 980.75 \\
\hline & June & 8.1 & 40.5 & 2.075 & 2.3 & 39.5 & 975.8 \\
\hline \multirow[t]{2}{*}{ Rainy } & July & 7 & 73.5 & 4.025 & 1.65 & 34.9 & 974.1 \\
\hline & August & 8.1 & 68.5 & 3.975 & 2 & 35.5 & 976.3 \\
\hline \multirow[t]{2}{*}{ Autumn } & September & 8.4 & 67 & 2.725 & 1.9 & 34.95 & 982 \\
\hline & October & 8.7 & 64.7 & 1.05 & 1.1 & 31.65 & 988.75 \\
\hline \multirow[t]{3}{*}{ Winter } & November & 6.1 & 62 & 2.425 & 0.65 & 26.2 & 991.05 \\
\hline & December & 5.3 & 70 & 1.45 & 0.4 & 19.2 & 993.55 \\
\hline & January & 5 & 28.6 & 2.175 & 3.78 & 19.85 & 992.3 \\
\hline
\end{tabular}

Figures 

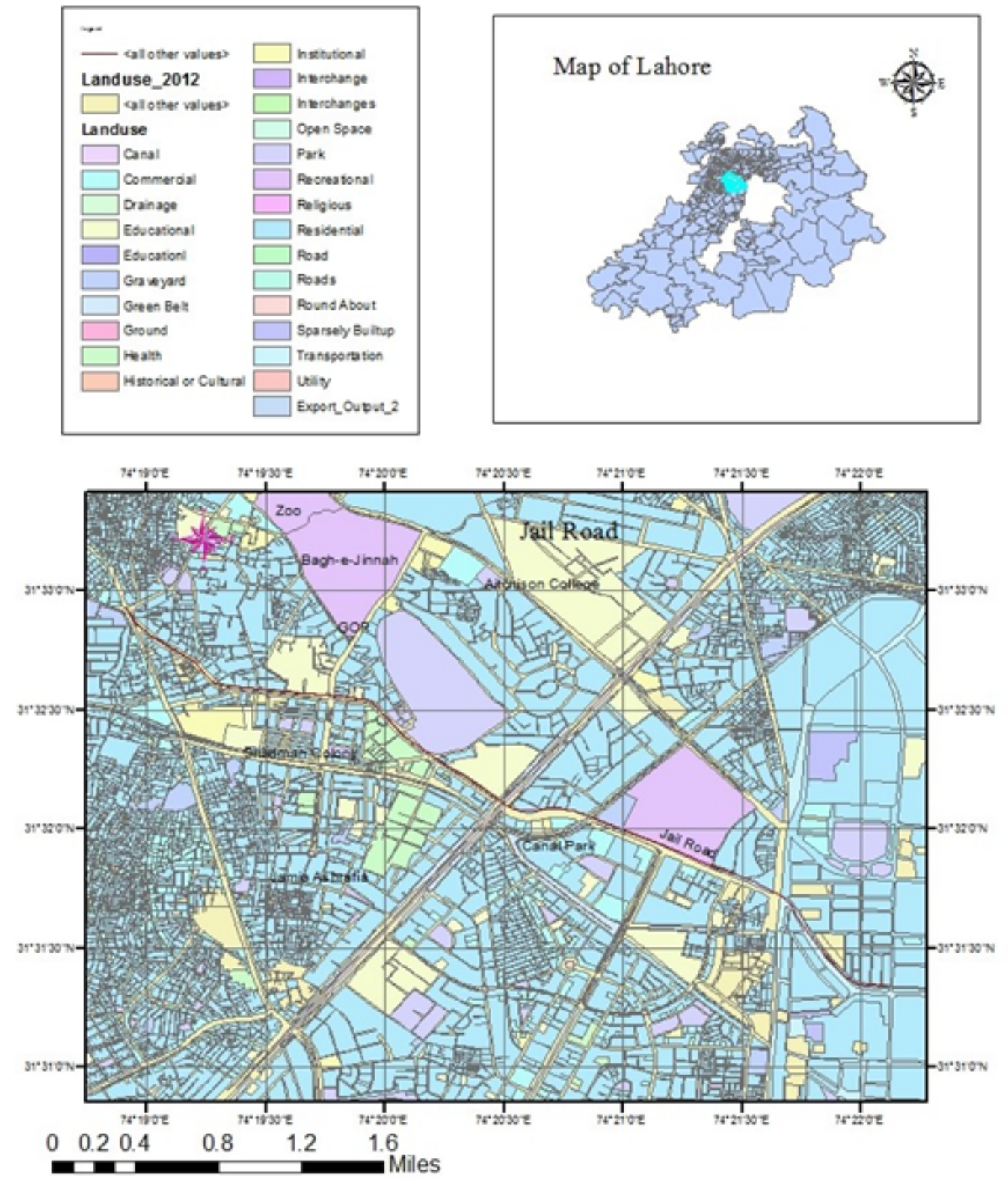

\section{Figure 1}

Commercial land use and Geographical coordinates of Jail Road , Lahore Note: The designations employed and the presentation of the material on this map do not imply the expression of any opinion whatsoever on the part of Research Square concerning the legal status of any country, territory, city or area or of its authorities, or concerning the delimitation of its frontiers or boundaries. This map has been provided by the authors. 


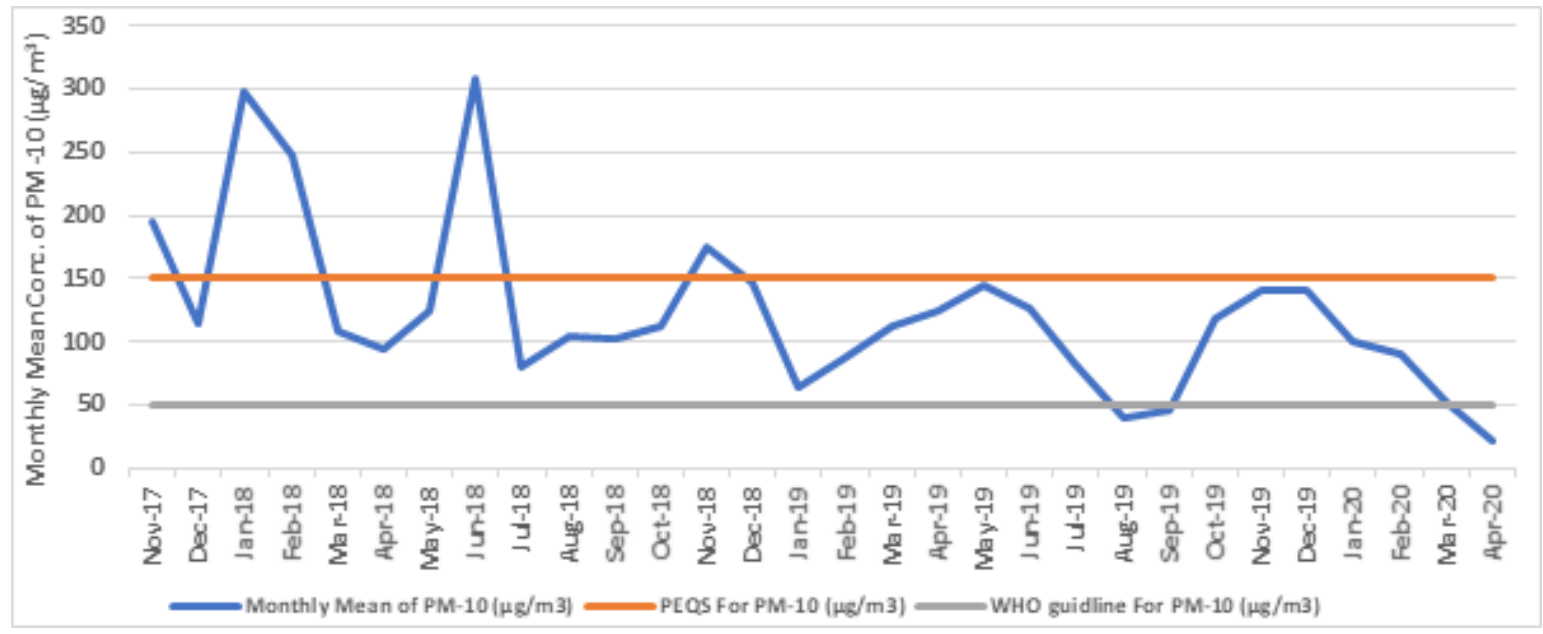

Figure 2

Temporal prevalence of PM10 in the ambient air of Jail Road and its compliance with PEQS,2016 and WHO Air Quality Guidelines,2005

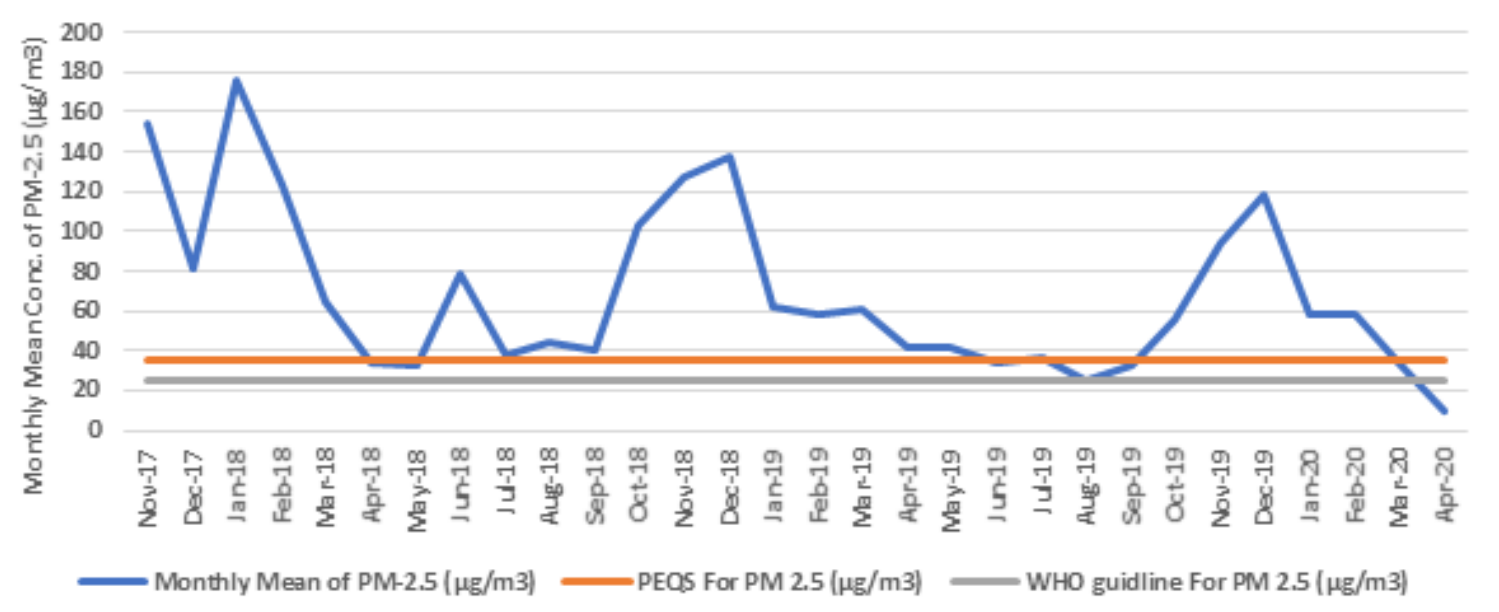

\section{Figure 3}

Temporal prevalence of PM2.5 in the ambient air of Jail Road and its compliance with PEQS,2016 and WHO Air Quality Guidelines,2005

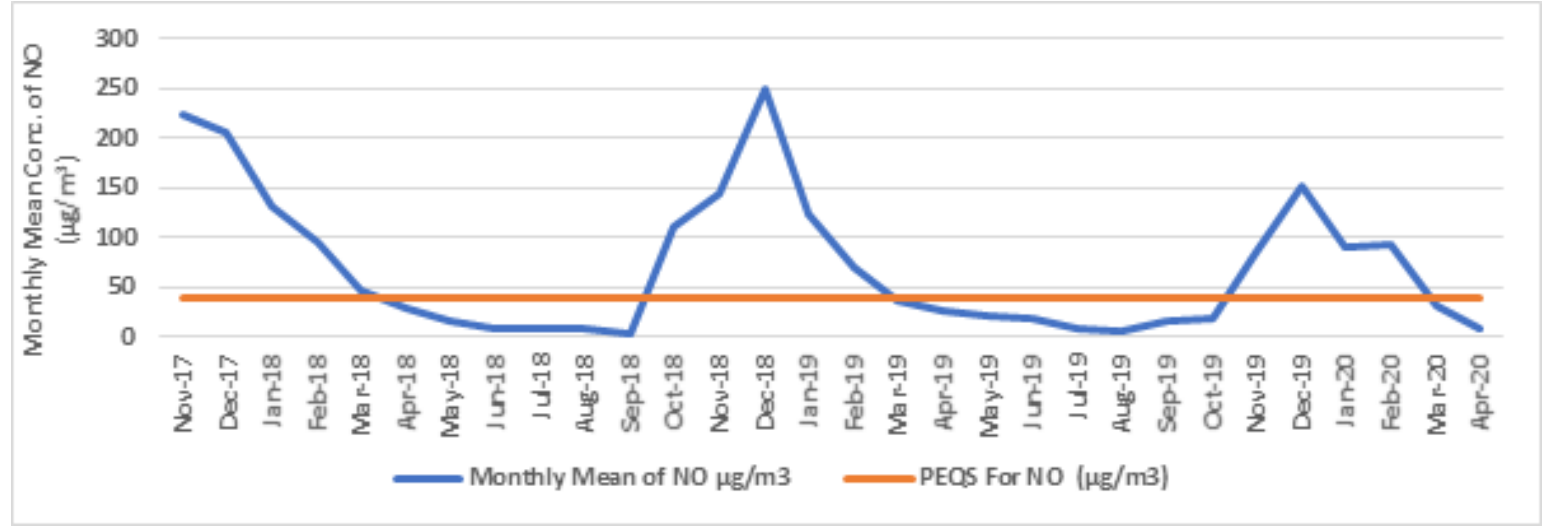

Figure 4 
Temporal prevalence of NO in the ambient air of Jail Road and its compliance with PEQS,2016

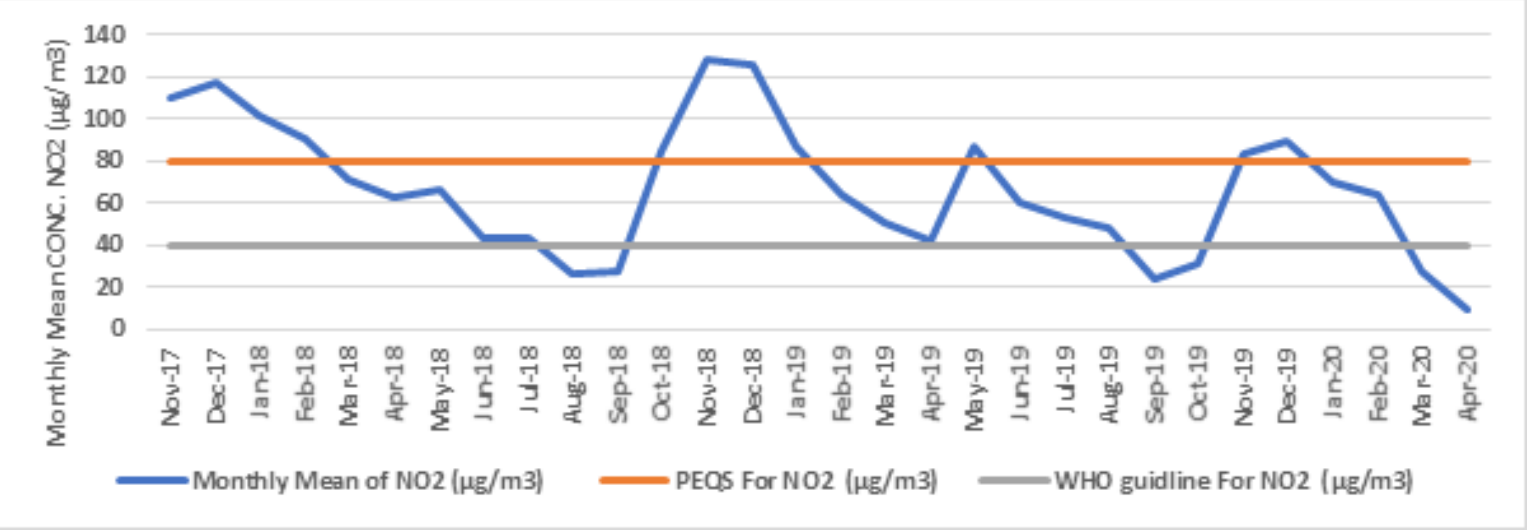

\section{Figure 5}

Temporal prevalence of NO2 in the ambient air of Jail Road and its compliance with PEQS,2016 and WHO Air Quality Guidelines,2005

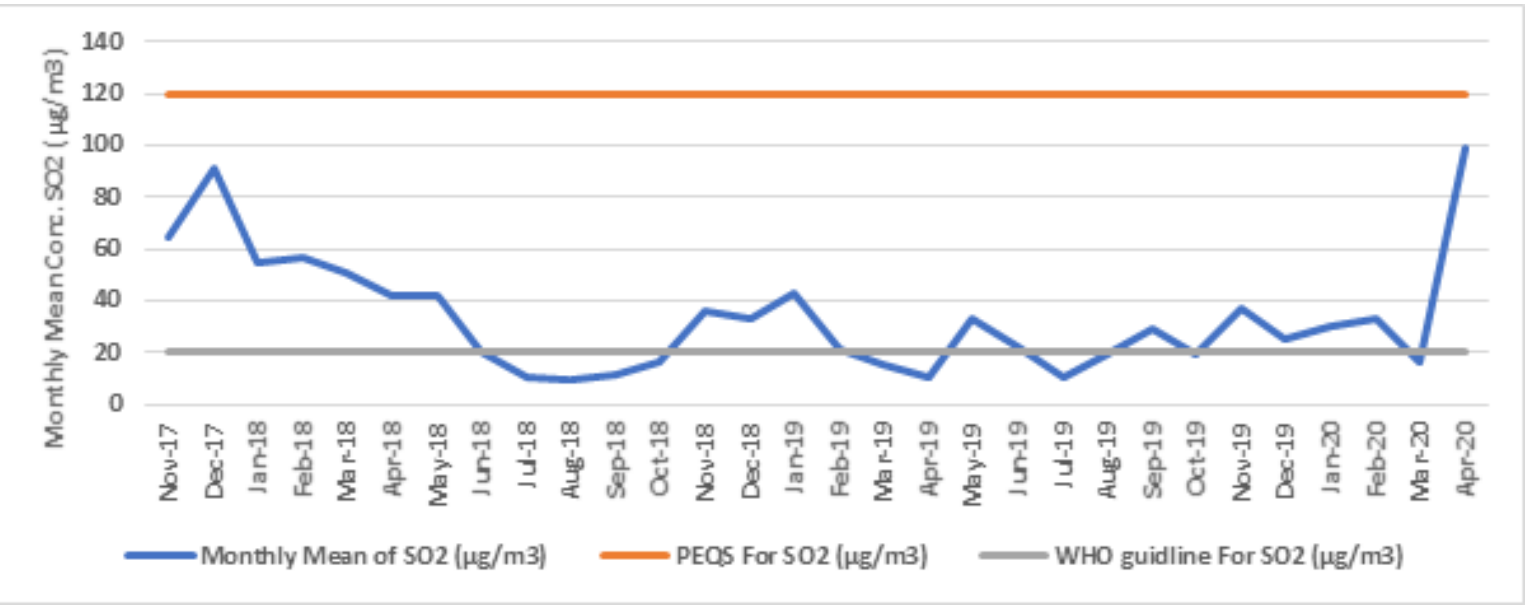

\section{Figure 6}

Temporal prevalence of SO2 in the ambient air of Jail Road and its compliance with PEQS,2016 and WHO Air Quality Guidelines,2005

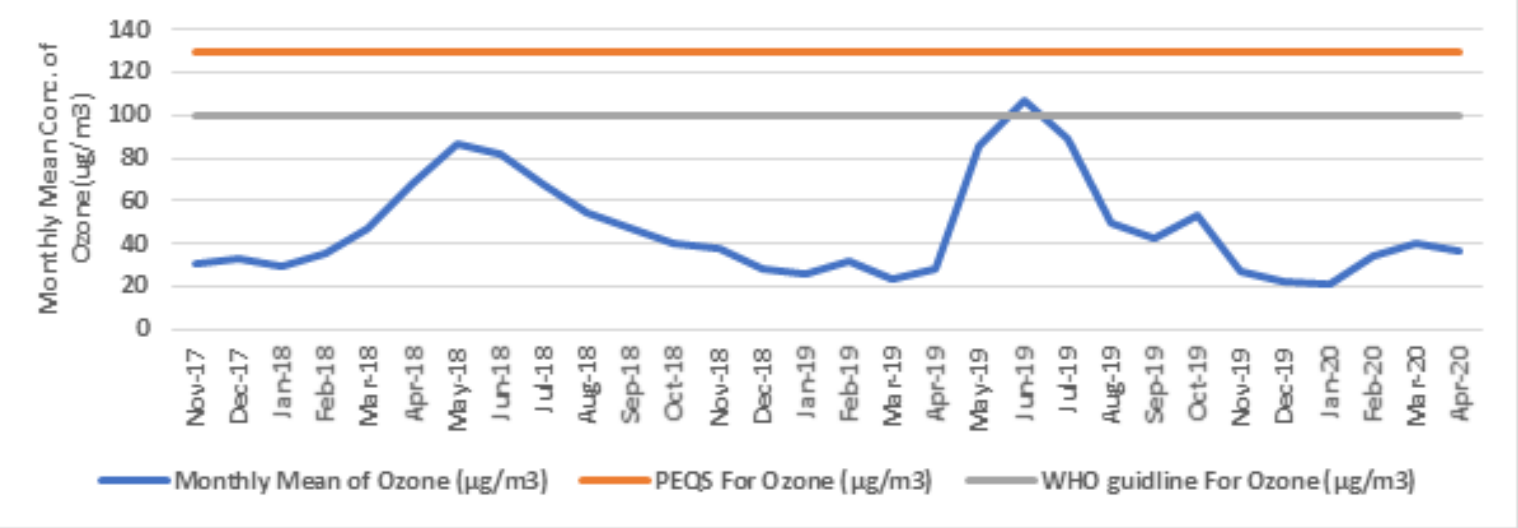

Figure 7 
Temporal prevalence of 03 in the ambient air of Jail Road and its compliance with PEQS,2016 and WHO Air Quality Guidelines,2005

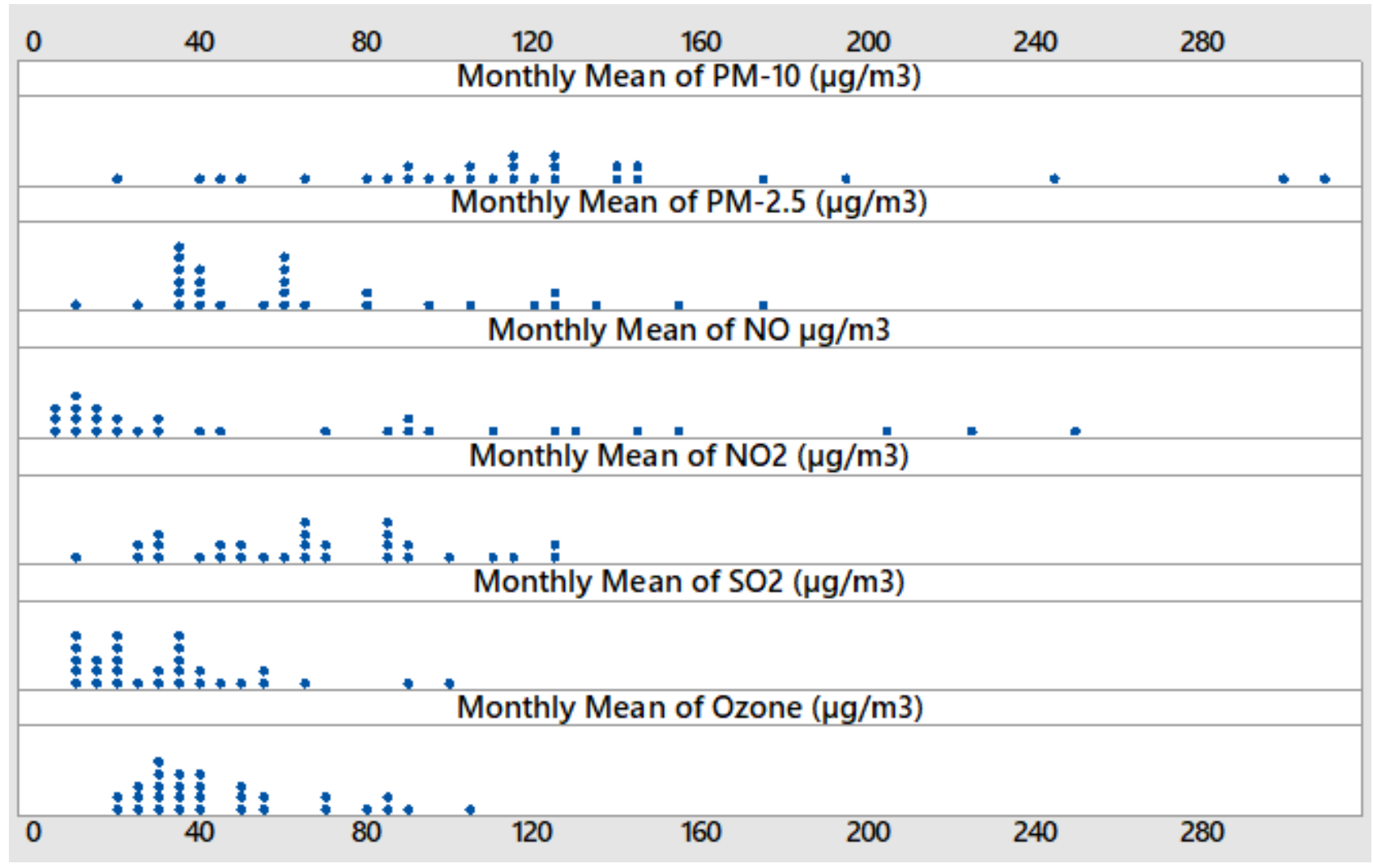

Figure 8

Dot plot is showing the Temporal concentration range of smog precursors in the ambient air of Jail Road 


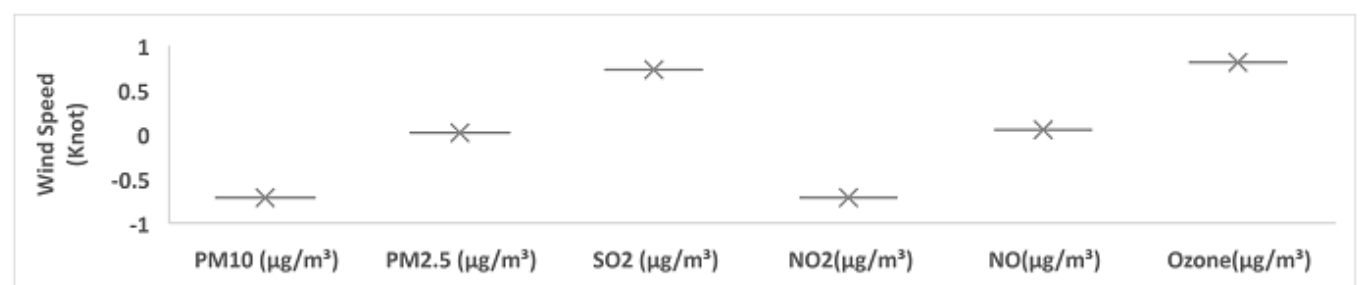

a.

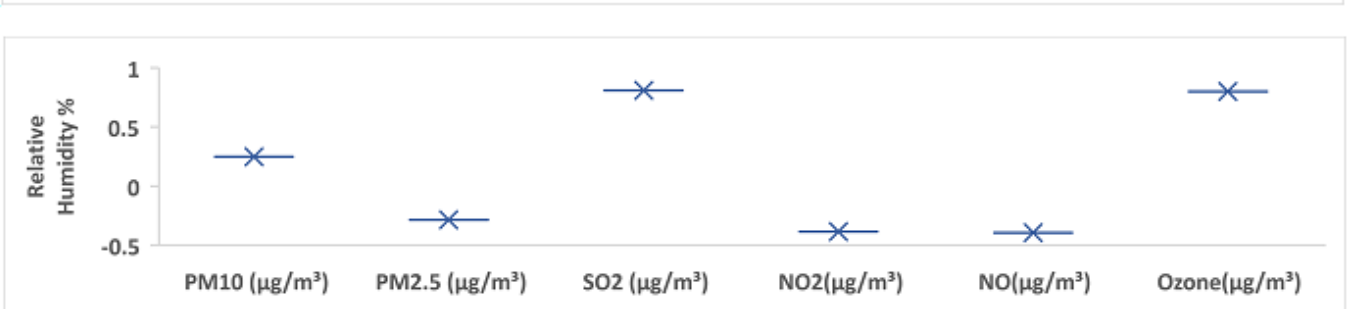

b.

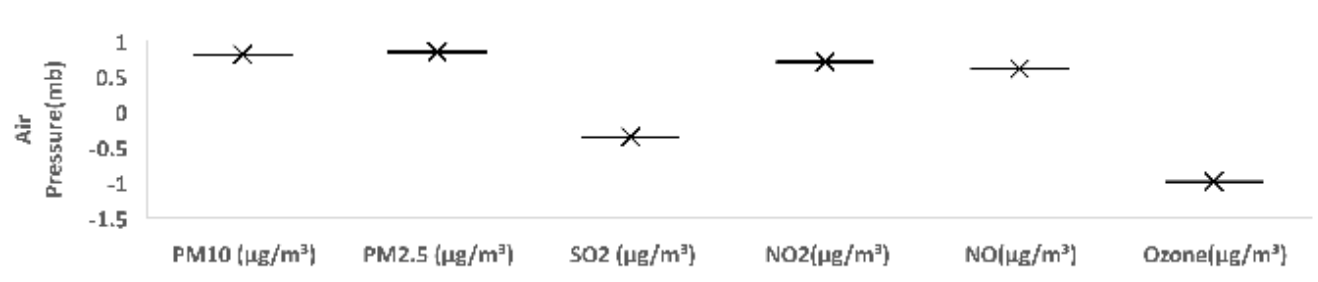

c.

d.
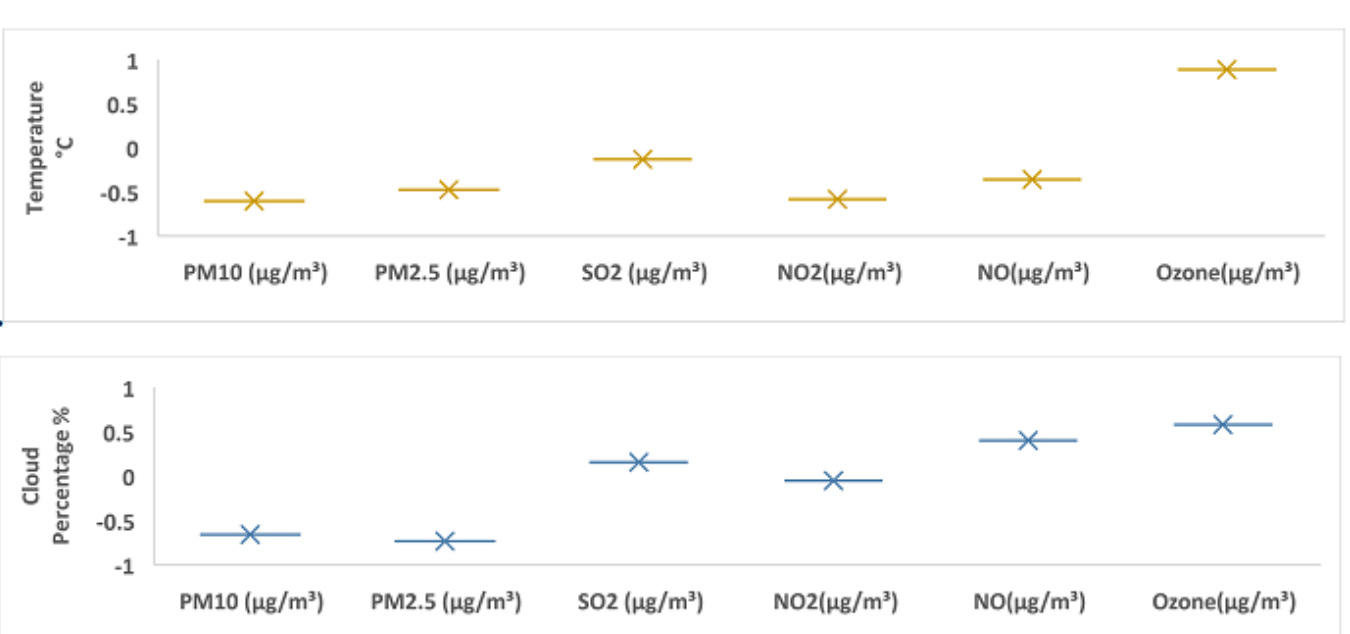

e.

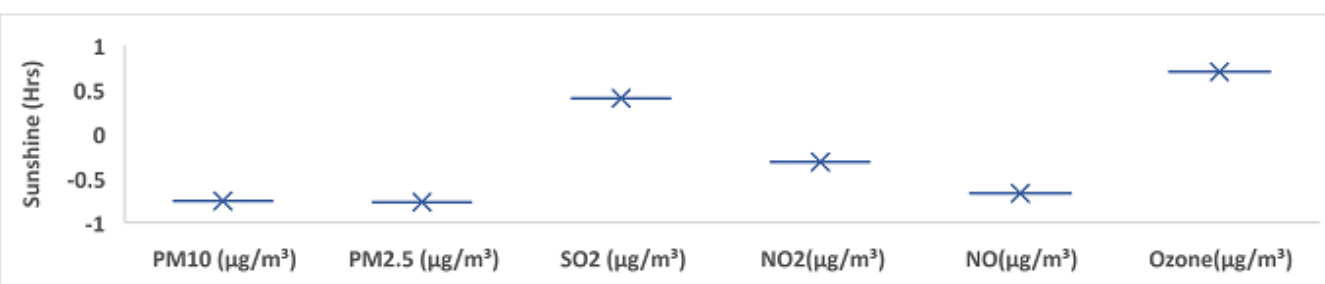

f.

Figure 9

Correlation of smog precursors with weather components

\section{Supplementary Files}

This is a list of supplementary files associated with this preprint. Click to download. 
- SuplementaryMaterial.xIsx

Page 18/18 